\title{
Does Right or Left Matter? \\ Cabinets, Credibility and Fiscal Adjustments*
}

\author{
José Tavares \\ Department of Economics \\ University of California Los Angeles
}

November 1999

Preliminary. Please Do Not Quote Without Permission.

* The author thanks Alberto Alesina, Mário Centeno, David Cutler, Jeffry Frieden, Fernanda Llussá, Francisco Rodriguez and Dani Rodrik, as well as participants in the Macro Workshop at Harvard University and the seminar at New University in Lisbon, for useful comments. Financial support from the Banco de Portugal and the Fundação para Ciência e Tecnologia is gratefully acknowledged. The usual disclaimer applies. 


\begin{abstract}
This paper uses the widely held assumption that left-wing cabinets prefer a larger size of government than right-wing cabinets to answer the question: does the pair cabinet ideology - fiscal action affect the persistence of fiscal adjustments? For a panel of OECD countries from 1960 to 1995, we find that left and right-wing cabinets are partisan in the expected way, namely, when cutting the deficit, the left relies on tax increases and the right on spending cuts. Our testable hypothesis is that cabinets signal commitment and gain credibility by pursuing fiscal adjustments in ways not favored by their constituents, i.e., the left cuts expenditures and the right increases taxes. Probit estimates of the impact of adjustment characteristics on the likelihood of success provide evidence in favor of the fact that cuts in spending by the left and tax increases by the right lead to more persistent adjustments than the reverse. These results are consistent with the literature on fiscal adjustments that has revealed that adjustments pursued by spending cuts are more persistent. We identify other adjustment characteristics that influence the persistence of the deficit cut: coalition cabinets, as well as majority cabinets, are less likely to be successful; a high level of public debt or a public debt that has been growing in the recent past tend to make the adjustment more credible. We also find evidence that private investment responds to the pair cabinet ideology - fiscal action in a way that is consistent with our hypothesis. First, cuts in spending by the left have a stronger stimulative effect on investment than cuts by the right, whereas increases in taxes by the left actually contract private investment, in contrast to the positive effect of tax increases by the right.
\end{abstract}




\section{Introduction}

In the last decade, a substantial research effort has been devoted to understanding the political economy of fiscal adjustments. Among the questions most often raised are the factors that increase the likelihood that a fiscal adjustment is successful. The most important answers rely on the type of cabinet undertaking the fiscal contraction, the economic context in which adjustment is attempted and the characteristics of the adjustment itself. Empirical findings have confirmed some of the priors widely held by economists and policy-makers; others run against what standard macroeconomic theory and conventional wisdom suggest. In a influential paper, Giavazzi and Pagano (1990) have shown that adjustments are not necessarily contractionary and may even be expansionary. Alesina and Perotti (1997) have shown that adjustments that rely on expenditure cuts, more specifically on cuts in transfers and the government wage bill, are more persistent than adjustments relying on tax increases. As to the circumstances of the adjustment, Perotti (1997) has shown that, when initiated in periods of fiscal distress (high deficits and high levels of public debt), adjustments are more likely to be successful.[theoretical literature] The word "credibility" is often invoked in explanations of why some adjustments are persistent and others not.

This paper conducts an empirical search for credibility effects in fiscal adjustments, investigating if the match between the ideology of the cabinet and the type of adjustment - cut in spending or increase in taxes - affects the probability of success. ${ }^{1}$ We claim that adjustments are more likely to be successful if left-wing cabinets cut spending or right wing cabinets increase taxes. "Credibility" is the explanation on which we rely to guide our investigation and interpret our results. The reasoning is straightforward. A major disagreement between left and right-wing cabinets in the economic sphere is over the ideal level of government intervention in the economy, reflected in the size of government. In other words, the left favors a larger share of government spending on GDP than the right. This disagreement between left and right is widely recognized by all individuals in the economy. ${ }^{2}$ Fiscal adjustments where the left decreases spending or the right increases taxes signal commitment or compromise, and should be more credible. By

\footnotetext{
${ }^{1}$ We understand success as a level of persistence in the deficit cut. In this paper, the terms success and persistence will be used interchangeably, when applied to fiscal adjustments.

${ }^{2}$ As expressed by Robert Samuelson, when commenting on the 1996 Clinton-Dole Presidential campaign in the United States: "(...) the real issue concerns government direction. Will it grow bigger and more activist? Or will it be more restrained and disciplined? And here genuine party differences exist." See Samuelson (1996).
} 
pursuing the policy that is the most painful to their constituents, cabinets can signal how urgent the fiscal adjustment is.

The study of the relation between cabinet ideology and the persistence of fiscal adjustments is important for various reasons. First, as shown in previous work, successful adjustments tend to be less contractionary than unsuccessful ones. If this fact is to be believed, understanding the factors that make adjustments successful will allow cabinets to cut deficits with lower costs to the economy. Second, as is also evident in previous research, centrist cabinets are seldom, if ever, successful when cutting deficits. If successful adjustments are invariably pursued by cabinets with a specific ideological inclination, then ideology probably is an essential part of the explanation of success. Third, there are strong priors regarding which fiscal actions by left and right-wing cabinets may signal commitment to cut the deficit. In this context, all we seek is to understand the response of economic variables to observables with a clear and shared meaning. Since it is easy to agree on the credibility of specific fiscal changes by left and rightwing cabinets, we are able to capturing the effects of a idea as elusive as credibility.

Two important facts about adjustments and success have been widely documented in the literature on fiscal adjustments. ${ }^{3}$

- Fiscal adjustments which rely on spending cuts are more persistent than those relying on tax increases;

- Fiscal adjustments initiated by left are at least as persistent as those initiated by right-wing cabinets;

In this paper, we begin documenting an additional fact that comes as no surprise given the conventional wisdom about left and right:

- When a left-wing cabinet cuts the deficits it tends to rely on tax increases, whereas the right tends to rely on expenditure cuts.

For the three facts above to be simultaneously true, it is necessary that left and right-wing cabinets have different success rates when cutting deficits in different ways. In summary, the left rarely cuts

\footnotetext{
${ }^{3}$ See Alesina and Perotti (1997) and Alesina, Perotti and Tavares (1998).
} 
expenditures when adjusting but, whence it does, it is very credible and the same holds true for the right and tax increases. This is the fundamental hypothesis to be tested in this paper.

The organization of the paper is as follows: Section 2 reviews the literature on fiscal adjustments and their persistence, as they relate to the concept of credibility. Section 3 documents the assumption that the left prefers a larger size of government than the right. We document preferences directly from surveys of individuals and policy-makers, review the literature on partisanship and government size and show that these preferences translate into fiscal policy outcomes. Importantly, we explain how cabinet ideology can translate into credibility and success. Section 4 presents Probit estimates of the impact of different adjustment characteristics on the persistence of adjustments. In Section 5 we present our conclusions.

\section{Credibility and Successful Fiscal Adjustments}

\subsection{Can Fiscal Adjustments Be Expansionary?}

In the standard Keynesian framework, under the assumption of sticky wages in the short-run, a cut in expenditures, or an increase in taxes, are contractionary policies, resulting in decreases in output, investment and consumption. The multiplier effect of expenditures and taxes, working through consumption and disposable income, are such that simultaneous cuts of the same magnitude in expenditure and taxes are still contractionary. ${ }^{4}$ The Keynesian result holds in a static world where individuals ignore how policy changes today affect economic variables in future periods. In particular, the effect of current policies on expectations about future policy is ignored. However, as been pointed out in Bertola and Drazen (1993) "a policy innovation that would be contractionary in a static model may be expansionary, if it induces sufficiently strong expectations of future policy in the opposite direction". Thus, a cut in the deficit undertaken by decreasing expenditures or increasing taxes (or both) can be expansionary if it leads to changes in the expected level of interest rates or public spending that work as a stimulus for consumption and investment.

Cuts in public spending can be expansionary in any model where today's spending changes the expected level of spending in the future. All spending is financed by taxes, now or in the future. A

\footnotetext{
${ }^{4}$ In other words, the "balanced-budget multiplier" is strictly positive.
} 
decrease in permanent spending leads to a concomitant decrease in the present discounted value of taxes. ${ }^{5}$ If a spending cut today signals a decrease in permanent spending, the net value of future taxes decreases and private wealth increases. As a result, consumption and output may increase. ${ }^{6}$

Increases in taxes can also lead to increases in output. A tax increase today may smooth the path of taxes over time, for a given level of public spending. If the distortionary costs of taxation are non-linear in the tax rate, the smoother tax leads to an increase in household wealth because consumers are being taxed in a more efficient manner. ${ }^{7}$ In addition to changing the path of taxation, tax hikes can lead to increases in consumption by resolving uncertainty over the future course of fiscal policy. In this case, the increase in output can work through a reduction in precautionary savings. ${ }^{8}$

An additional channel through which fiscal policy changes household wealth (labor and non-labor) is through a change in the interest rate. A decrease in the deficit may lead to a decrease in the interest rate and an increase in private wealth. If private consumption is affected by private wealth, output in the economy can increase. ${ }^{9}$ A deficit cut would, in this case, be expansionary. Credible cuts in the public deficit lead to decreases in interest rates through lower expected inflation and lower default risk premia. The more credible the adjustment, the larger the change in interest rate and the stronger the expansionary effect.

\subsection{Sources of Credibility}

\footnotetext{
${ }^{5}$ This is a corollary of the well-known Ricardian Equivalence result that purports that changes in the deficit today do not lead to any change in consumption, interest rates or output if government spending is unchanged and individuals discount future taxes appropriately. See Barro (1989).

${ }^{6}$ Public expenditure, particularly in education and health, is a substitute for private consumption. If this is the case, the decrease in government consumption should, other things equal, lead to a compensating increase in private consumption. Giavazzi and Pagano (1990) show that, for the 83-84 stabilization in Denmark, private consumption tends to increase in items where government consumption has been cut. In this paper we will ignore this fact since this effect is operative for a small group of items accounting for a fraction of total private consumption and the effects, as assounted for in Giavazzi and Pagano (1990) are not very strong.

${ }^{7}$ This argument is made in Blanchard (1990).

${ }^{8}$ On the other hand, tax increases may be contractionary through reduced work effort. For a given level of spending, tax increases have two effects on work effort: the wealth effect leads to increased work effort, higher consumption and output; the substitution effect leads to reduced work effort, lower consumption and output. If the tax cut is temporary, the substitution effect is likely to dominate, but if the tax increase is permanent, the wealth effect tends to dominate. However, as documented in Pencavel (1986), this substitution effect is likely to be small.
} 
In this section we examine successful and unsuccessful fiscal adjustments, in an attempt to identify possible sources of credibility that explain the success in cutting the deficit. We define fiscal adjustment as a cut in the deficit of at least 1.5 percent of GDP, in a single year. Fiscal adjustments can be successful or unsuccessful, depending on the persistence of this initial deficit reduction. The credibility of the fiscal adjustment, i.e. how permanent the change in the deficit is believed to be, is a key element in the success of the adjustment. Deficit cuts that are perceived as permanent - i.e., unlikely to lead to fiscal actions that reverse them in the future, tend to be credible. Credible fiscal adjustments induce an expansionary effect, which directly leads to decreases in the deficit and the public debt as shares of GDP, ultimately contributing to the persistence of the original adjustment. The existing literature on fiscal adjustments provides several candidates as sources of credibility. We now turn to a summary review of those different factors.

The first source of credibility is the size of the deficit cut. Giavazzi and Pagano (1990) were the first to carefully document the success of the very tight Irish and Danish adjustments of the mid-80's. In a later paper, the authors presented some evidence of a correlation between large cuts and increases in private consumption. ${ }^{10}$. The larger the cut in the deficit, the reasoning goes, the more credible it is and thus the stronger its expansionary effects. However, Alesina and Perotti (1997) find little association between size of the deficit cut and success.

A second source of credibility is the composition of the deficit cut. Alesina and Perotti (1997) document how adjustments relying mostly on spending cuts tend to be more successful than adjustments relying on tax cuts. The components of public expenditure that are cut the most in successful adjustments are government wages and transfers. It is pointed that cuts in major eligibility programs or public employment are likely to be more permanent than cuts in non-wage public consumption and public investment. The fact that the government is willing to cut spending "the hard way" signals to the public how the seriousness of the cabinet's intentions. The public understands that these adjustments harm

\footnotetext{
${ }^{9}$ Increases in private wealth may have contractionary effects if consumers value leisure: the wealthier consumers are, the more leisure they want to consume, and fewer hours worked mean a lower level of output. As argued below, this effect is likely to be small.

${ }^{10}$ See Giavazzi and Pagano (1996).
} 
specially powerful constituencies such as trade union members and pensioners and thus assigns them higher credibility. ${ }^{11}$

The type of cabinet may also affect credibility. Alesina and Drazen (1991) and Spolaore (1993) have shown formally how coalition cabinets are less likely to reach agreement in such matters as when and how to cut a government deficit. A coalition government has more difficulty than a single party majority government to assign the costs of adjustment to specific groups since coalition partners are likely to veto some of the possible options. This theoretical argument can be easily extended to show how coalition cabinets are more likely to break an agreement over an adjustment, after it has been initiated. Empirically, it has been shown that coalition cabinets are tend to be more fiscally irresponsible than other cabinets, increasing expenditures at the cost of larger deficits. ${ }^{12}$ The resulting message of this literature is that adjustments initiated by coalition cabinets are less likely to be successful.

The circumstances of the adjustment, namely the level and increase in public debt in the years before the adjustment and its change in the years prior to the adjustment, also affect credibility. Sutherland (1995) shows that, in a model where consumers have finite lives, a decrease in spending (or increase in taxes) have contractionary effects at low debt levels but are expansionary at high debt levels. These nonmonotonic effects of fiscal policy are explained by the fact that, when the fiscal situation is serious, the decrease in spending or increase in taxes decreases the likelihood of an early stabilization and may postpone the cost sufficiently into the future that consumption increases. ${ }^{13}$ Perotti (1997) has presented empirical evidence showing that, when public debt is high, deficit cuts are more likely to be expansionary.

An additional possibility, not yet exploited in the literature, is that the stage of the business cycle at the time of adjustment influences credibility. Cuts in the deficit which occur in recessions when output is temporarily low and unemployment is high may be more credible. These adjustments, precisely because they involve extra economic pain, are not likely to be seen as temporary policies or as results of the economic fluctuations.

\footnotetext{
${ }^{11}$ Alesina, Perotti and Tavares (1998) showed that the electoral success of cabinets is not affected by the size of the cut. If anything, larger deficit cuts and cuts in government wages may increase the probability of survival of the cabinet. The reason why cabinets don't adjust more often has to be that governments are sympathetic or affraid of particular interest groups.

${ }^{12}$ See Roubini and Sachs (1989) and Grilli, Masciandaro and Tabellini (1991).

${ }^{13}$ Bertola and Drazen (1993) also present a model where cuts in spending have different effects at different levels of public spending but they do not derive clear empirical implications.
} 
In Table I below we present summary statistics for a set of variables at the time fiscal adjustments were initiated. The objective is to identify possible determinants of success highlighted above. Formally, we define an adjustment episode as successful if at least one of the following conditions holds:

1. In the three years after the tight period, the ratio of the primary deficit to GDP is on average 2 (or more) percent of GDP below its level in the initial year of the adjustment;

2. Three years after the initial adjustment year, the debt to GDP ratio is at least 5 percent of GDP below its level in the last year of the tight period.

The data, for a set of 19 OECD countries in the 1960-1995 time period, is described in detail in Appendix I. The distribution of fiscal adjustments in the sample, by country and by year, is presented in Appendix II. As can be easily verified, adjustments are fairly well distributed in both dimensions, even if there are countries that are particularly prone to adjustments and adjustments tend to occur in the mid-70s and mid to late 80 's.

As reported in the literature, the size of the deficit cut is not radically different for the two types of adjustments, even if it is larger for successful adjustments. There is a strong composition effect: successful adjustments are those that reduce spending rather than increase taxes. As to cabinet characteristics, coalition cabinets are less likely and minority cabinets more likely to be associated with successful adjustments. Most notably, the level and the change in public debt are higher just before successful adjustments. The level of public debt is 22 percent higher and its change 10 percent higher than before unsuccessful adjustments. Both successful and unsuccessful adjustments are attempted at similar stages of the business cycle even if successful adjustments tend to occur when unemployment is decreasing rather than increasing. Summing up, several candidates for source of credibility in fiscal adjustments seem to be strongly related with success. An attempt to explain success should not ignore these different factors. 
Table I

Characteristics of Successful Adjustments

\begin{tabular}{|c|c|c|}
\hline & $\begin{array}{l}\text { Successful } \\
\text { Adjustments }\end{array}$ & $\begin{array}{l}\text { Unsuccessful } \\
\text { Adjustments }\end{array}$ \\
\hline CHDEF & -2.68 & -2.15 \\
\hline CHEXP & -1.70 & -0.63 \\
\hline CHREV & 0.97 & 1.52 \\
\hline LAGDEBT & 71.04 & 44.02 \\
\hline CHDEBT & 14.76 & 4.78 \\
\hline$\Delta \mathbf{G D P}$ & 3.19 & 3.56 \\
\hline$\Delta \mathbf{U N R}$ & -0.50 & 2.07 \\
\hline COAL & 29 & 67 \\
\hline MIN & 57 & 12 \\
\hline Number Observations & 21 & 51 \\
\hline
\end{tabular}

CHDEF, CHEXP and CHREV are, respectively, the change in the primary deficit, primary public expenditures and government revenues as share of Gross Domestic Product. LAGDEBT and CHDEBT are the level of public debt and the change in its level in the last 3 years, as share of GDP. $\triangle G D P$ and $\triangle \mathrm{UNR}$ are the rate of change of real GDP and the unemployment rate. COAL is the relative frequencies of coalition cabinets for each outcome. See Appendix I.

\section{Ideology, Fiscal Policy and Credibility}

In this section, we motivate and document the source of credibility that is the focus of this paper: the interaction between cabinet ideology and the composition of the adjustment.

\subsection{Are Left and Right Fiscally Different?}

To support the claim that left-wing cabinets have a preference for a higher level of public spending we will look at three types of evidence: survey data collected through interviews with individuals of given ideological persuasion; results from the empirical literature on ideology and fiscal policy; finally, we present summary statistics for fiscal policy changes by left and right cabinets in OECD countries. It is important to understand what will not be the subject of our attention. First, we will not discuss the general origin of the character of left and right; we are only interested in differences as far as fiscal behavior is 
concerned. ${ }^{14}$ We will also not specifically address the origin of the diverging preferences for government size. ${ }^{15}$ For our purposes it suffices that the difference in preferred size of government exists and is operative in fiscal policy.

\subsubsection{Asking People}

A few surveys have documented the association between voter ideology and fiscal preferences. Kay et al. (1995) reports results from interviews conducted in 1992 and 1995. A broad sample of individuals was asked to locate themselves in the Republican-Independent-Democrat and the Conservative-Moderate-Liberal spectra. ${ }^{16}$ These same individuals were then asked the question: "In order to reduce the deficit, what is your desired percentage decrease in spending for each point increase in taxes?" The question mentions explicitly tax increases and spending cuts and thus captures precisely what we are interested in: the individual trade-off between the benefits of public spending and the costs of taxation. The survey results are presented in Table II. In both 1992 and 1995, and for each point of increase in taxes, Republicans favor larger spending cuts than Democrats. The difference is not negligible: 0. 55 and 1.20 percent of GDP, in 1992 and 1995 respectively. Moreover, the difference between people labeling themselves Conservative and Liberal is similar to that between Republican and Democrat. Finally, it is remarkable that middle of the road voters (Independents/Moderates) display middle of the road fiscal preferences, i.e., they favor spending cuts that are larger than those favored by the left, but smaller than those favored by the right. These results suggest that preferences over the level of public spending are systematically associated with preferences on a broader set of political issues that determine individual political alignment.

\footnotetext{
${ }_{15}^{14}$ For a general discussion on the relevance of left-right ideological orientation, see Lewis-Beck (1988).

15 The obvious candidate is that parties cater to different constituencies and parties on the left cater to a lower income constituency who benefits more from public expenditure programs and/or faces lower tax rates. Piketty (1995) quotes survey evidence associating income and voter preferences that supports the contention that lower income individuals tend to vote with the left.

${ }^{16}$ The use of the two dimensions attempts to correct for prejudices associated with specific labels that could bias results. However, as will be evident, the results do not depend in any way on the labels used.
} 
Table II

Republicans, Democrats and Fiscal Preferences

\begin{tabular}{l|cc}
\hline & 1992 Survey & 1995 Survey \\
\hline Conservative & 2.17 & 2.85 \\
Moderate & 1.60 & 2.08 \\
Liberal & 1.30 & 1.86 \\
& & \\
Republican & 1.98 & 2.97 \\
Independent & n.a. & 2.28 \\
Democrat & 1.43 & 1.75 \\
& & \\
Sample Average & 1.7 & 2.26 \\
\hline
\end{tabular}

Source: Kay, Henderson, Steeper, Greenberg and Blunt (1995). Survey I was conducted in 1992 and survey II in 1995. The question posed in both surveys was : In order to reduce the deficit, what is your desired percentage decrease in spending for each point increase in taxes?

A second piece of evidence is from the Gallup Poll Monthly (1990). Individuals are asked whether they would be more or less likely to vote for a senator who had voted for a tax increase. 30 percent of the individuals who classified themselves as Democrats said they would be less likely to vote for the senator, compared with 42 percent of the Republicans. ${ }^{17}$ This difference, replicated in differences between Conservatives and Liberals, was larger than for most other individual categories studied, such as gender, age, race and education groups.

What about policy-makers preferences? Do they reflect the fiscal preferences of their constituents? We rely on Fuller et al. (1995), who asked delegates to the 1992 Democratic and Republican Party conventions whether they agreed, disagreed (or had no opinion) on a series of economic policy statements. For each statement, the authors reported the degree of consensus within each party and whether the difference between parties was significant.

In Table III, we report answers to five statements: statement 7 is the one closest to our issue of interest, the desired size of government; statements 6 and 9 address issues of deficit management; statements 13 and 39 are strongly ideological and are reported for illustrative purposes. Examining the

${ }^{17}$ And 35 percent of the Independents. 
strongly ideological statements first, we verify that the delegates' positions differ substantially between parties: almost all Republicans display a strong belief in the regenerative virtues of a market economy, but very few Democrats share that belief; more than two thirds of the Democrats think there should be more redistribution, while roughly two thirds of the Republicans disagree. Thus, party delegates are not all alike: they share beliefs with delegates from their own party that are at odds with beliefs prevalent in the other party. Statements 6 and 9 show, on the other hand, that there can be agreement over certain issues. Substantial and similar-sized majorities among both Republicans and Democrats agree that large deficits have adverse effects on the economy but can be stimulative in a recession. Thus, as far as deficit management is concerned, there is no evidence of strong partisan differences. ${ }^{18}$

\section{Table III}

\section{Republicans and Democrat Party Delegates and Fiscal Preferences}

\begin{tabular}{|c|c|c|}
\hline & Agree & Disagree \\
\hline \multicolumn{3}{|c|}{ Question 7 - Government Spending Should Be Reduced. } \\
\hline Republicans & 80.3 & 3.8 \\
\hline Democrats & 45.0 & 22.5 \\
\hline \multicolumn{3}{|c|}{ Question 6- Budget Deficits Have an Adverse Effect on Economy. } \\
\hline Republicans & 89.3 & 3.1 \\
\hline Democrats & 45.0 & 7.1 \\
\hline \multicolumn{3}{|c|}{ Question 9 - Fiscal Policy Has a Stimulative Impact on the Economy. } \\
\hline Republicans & 70.3 & 10.7 \\
\hline Democrats & 64.3 & 18.2 \\
\hline \multicolumn{3}{|c|}{ Question 13 - Economy Will Recover if Markets Are Left Alone. } \\
\hline Republicans & 70.7 & 12.4 \\
\hline Democrats & 13.2 & 72.1 \\
\hline \multicolumn{3}{|c|}{ Question 39 - The Distribution of Income Should Be Made More Equal } \\
\hline Republicans & 10.0 & 76.4 \\
\hline Democrats & 69.7 & 8.9 \\
\hline
\end{tabular}

${ }^{18}$ This is consistent with the finding in Blinder and Holtz-Eakin (1984) that individual ideology has no direct effect on support for a balanced-budget amendment. 
Finally, we look at the statement that is closest to the issue of the size of government. Around 80 percent of the Republicans but only 45 percent of the Democrats, agree that government spending should be reduced as a share of GDP. Moreover, only 4 percent of Republicans, compared with 22 percent of Democrats, disagree with the statement. So, even though partisan positions on government size are not as polarized as for the ideologically charged statements, the evidence strongly supports the existence of differences between parties on this issue. ${ }^{19}$

In sum, the evidence in this section points towards significant differences in preferences for the size of government across political parties, while there seems to be no divergence in deficit policy.

\subsubsection{Partisanship and Fiscal Policy}

Both economists and political scientists have investigated whether differences in party ideology translate into differences in fiscal policy. As far as total spending is concerned, Cameron (1978) has shown that the partisanship of electorate -- specifically the percentage of the government's electoral base composed of social-democrat or labor parties -- explains the increase in public spending share of the GDP in industrialized countries. ${ }^{20}$ Roubini and Sachs (1989) find that left-wing cabinets exhibit higher levels of public spending. In a longitudinal study of the US, Lewis-Beck and Rice (1985) analyze the growth of public spending from 1932 to 80 and find that an index of the strength of the Democratic party is positively related to spending. Golden and Poterba (1980) also uncover a strong party effect in their study of US government spending between 1952 and 1978. Alt and Lowry (1994) conclude "(...) Democrats target spending (and taxes) to higher shares of state-level personal income." On the other hand, Rice (1986) finds more ambiguous results for Western Europe: partisanship had a significant effect on spending in only six out of twelve countries examined. Blais, Blake and Dion (1993) concluded that "parties do make a difference, but a small one".

\footnotetext{
${ }^{19}$ Fuller et al. (1995) test the significance of differences between parties for each issue. For the statement on government size, the difference between parties is found to be statistically significant at the highest confidence level; the differences over statements related to deficit management are not significant.

${ }^{20}$ Swank (1988) has updated Cameron's study. He found that the proportion of "rightist" seats in Parliament is negatively related with spending during the 1960-73 period, whereas "centrist" parties seem to be the big spenders in the $1973-80$ period.
} 
As to the components of public spending, Castles (1982) shows that, in a cross-section of OECD countries in 1970 and 1980, the level of public spending on education and welfare is higher in countries where the left controls more cabinet seats. The increase in both spending categories is larger the higher the percentage of cabinet seats held by the left. Hicks and Swank (1992) examine 18 industrialized democracies between 1960 and 1982 and show that left-wing governments increase the share of welfare spending in GDP.

As to partisan effects on the size of the deficit, popular wisdom assumes that left-wing cabinets are more prone to deficit spending. Empirical studies, however, consistently find no strong evidence of such pattern of behavior. Cameron (1985), Cowart (1978) and, more recently, Hahm, Kamle and Mowery (1995) find no association between partisanship and the size of the deficit. Large deficits pursued by conservative cabinets in the US and Sweden in the 1980's actually led to the argument, developed formally in Persson and Svensson (1989), that right has an incentive to increase deficits as a way of constraining future spending by left-wing cabinets.

What does actual fiscal data reveal about left-right partisanship, public spending and taxation? With the discussion above in mind, we turn to a data set containing fiscal and political information on 19 OECD countries from 1960 to $1995 .^{21}$ The classification of cabinets into left and right is taken from Budge et al. (1993) and updated through 1995. The criterion used is based on the share of cabinet seats held by different parties, which have been previously located on a left-right scale. ${ }^{22}$ In years where more than one cabinet held power, the characteristics of the cabinet that remained in power the longest are used. Table IV presents the results regarding fiscal behavior in the OECD, namely the change in public spending, total revenues and their components for the subsamples of left and right cabinets. We also present the same fiscal variables in years where the deficit was cut by at least 1.5 percent of GDP.

The first fact displayed in Table IV is that the average change in deficit is remarkably similar between left and right cabinets. Even in adjustment years the deficit cut does not differ substantially between left or right-wing cabinets: the difference is around 0,1 percent of GDP. This seems to confirm previous results in the literature that do not see an association between partisanship and deficits.

\footnotetext{
${ }^{21}$ Appendix I describes the data set.

${ }^{22}$ See Castles and Mair (1984).
} 
Regarding public spending, the average yearly increase for left-wing cabinets was 0.54 percent of GDP in our sample, compared with 0.44 percent for right-wing cabinets.

\section{Table IV}

Left and Right and Fiscal Policy

\begin{tabular}{|c|c|c|c|c|}
\hline & \multicolumn{2}{|l|}{ Whole Sample } & \multicolumn{2}{|c|}{ Fiscal Adjustments } \\
\hline & Left & Right & Left & Right \\
\hline CHDEF & 0.07 & 0.08 & -2.30 & -2.43 \\
\hline CHEXP & 0.54 & 0.44 & -1.01 & -1.55 \\
\hline CHREV & 0.47 & 0.37 & 1.29 & 0.88 \\
\hline Number of Observations & 214 & 347 & 32 & 41 \\
\hline
\end{tabular}

Given the difference in spending patterns and the similarities in deficit policies, we expect cabinets controlled by the left to increase taxes by more than the right. The average yearly change in total revenues is larger by 0.1 percent of GDP in the case of left-leaning cabinets. Changes in indirect and other taxes explain the difference. ${ }^{23}$ In sum, for the sample of all observations, there is no evidence of a relationship between ideology and the average deficit, while there is some evidence that the left tends to increase spending and taxes more than the right. ${ }^{24}$

But the important difference emerges in adjustment years. When a cabinet decides to cut the deficit, it has the choice of relying mostly on spending cuts or tax increases. Table IV shows that the left increases taxes more than it cuts expenditures while the right does exactly the opposite. More than half of the adjustment by the left relies on tax increases while almost two-thirds of the adjustments by the right rely on spending cuts. This, we believe is what most economists and policy-makers would take as their prior. On average, the left cuts public spending only by 1 percent of GDP, while the right cuts spending by 1.55 percent of GDP. Most of this difference between left and right is accounted for by government wages and non-wage consumption and transfers. As to tax revenues, their yearly average increase in adjustments

\footnotetext{
${ }^{23}$ In the case of direct taxes on business, right-wing cabinets actually tend to decrease them as share of GDP, which runs contrary to the trend towards increasing government taxation during the period of study.
} 
led by a left-wing cabinet is 1.29 percent of GDP, while the right increases taxes by a more modest average of 0.88 of GDP. During adjustments the left increases taxes by more than the right and this is true of all major tax categories. This evidence suggests that cutting the deficit is not the sole objective of cabinets; they try to do it in a way that accords with their preferences and that harms their constituents the list. It is likely that cabinets can gain credibility by adjusting in a way that goes against their constituents' interests.

\subsection{Why Right or Left Should Matter}

There are at least two ways for the government to cut the primary public deficit: to cut public spending or to increase taxes. If a left-wing cabinet increases taxes (or a right-wing cabinet cuts spending), the policy is likely to be perceived as partisan behavior rather than a sign of a serious willingness to cut the deficit. Deficit cuts which are perceived as partisan, are more likely to be reversed by future cabinets of opposite ideological persuasion. On the other hand, a spending cut by the left or a tax increase by the right are credible policies since they give individuals in the economy information about the need and the benefits of adjusting. By pursuing actions that cannot be interpreted as furthering their self-interest, that imply a higher self-imposed cost, cabinets signal that the benefits associated with the policy are concomitantly larger. This is an application of the "why it takes a Nixon to go to China" argument, formalized in Cukierman and Tommasi (1998): an ideological policy-maker signals the potential benefits of a policy when it follows a policy known not to be her preferred one.

Thus, the story that backs our search for differential effects of fiscal policies by left and right-wing cabinets rely on the following assumptions:

- Asymmetric information: the economic benefit of cutting the deficit is uncertain and the cabinet has better information than the public; the cost of fiscal adjustments, namely the increase in taxes and/or decrease in expenditures, is recognized by policy-makers and the public;

- Partisanship: policy-makers are ideological, that is, the public knows what is their preferred course of action; in the case of fiscal adjustments, each cabinet prefer either to cut spending or to raise taxes;

\footnotetext{
${ }^{24}$ The maxima and minima for these changes are consistent with information on the averages: the maximum and minimum sample yearly changes in spending and taxes are higher for the left than for the right.
} 
- Signaling: by pursuing policies that are against their immediate interests, policy-makers provide information on the economic benefits from fiscal adjustments; left-wing cabinets signal commitment by cutting spending and right-wing cabinets by increasing taxes;

- Feedback: a sign of commitment to the policy improves the chances of it being successful; in the case of fiscal adjustments, a perceived commitment to the cut in the deficit unleashes a reaction by the public that increases the likelihood of the policy being persistent;

The criterion for success used in this paper and explained in section 2 relies on the persistence of the deficit cut. As mentioned above, this criterion is more likely to be met when one of the following occurs: the initial change in public spending and/or taxes is condoned by future cabinets; following the adjustment, there is an expansion in Gross Domestic Product. Adjustments where the left cuts public spending or the right increases taxes are more likely to be persistent for both of the reasons above: the initial fiscal action is likely to be validated by future cabinets; because it is credible, the fiscal action is likely to induce individual agents to increase consumption and investment and this expansionary response promotes the persistence of the adjustment. This is the feedback mechanism alluded to above.

Previous studies have uncovered that adjustments which rely on spending cuts are the most successful, as documented in Table I above. In Table IV we can verify that left and right are partisan specially when they adjust so that the right is more likely to cut spending than the left. These two facts lead us to expect the right to be more successful than the left. However, as Table V shows, that is not the case. The existing literature on fiscal adjustments has shown that Left and Right have similar success rates. ${ }^{25}$ In our extended sample, if anything, the Left is more successful than the right.

\footnotetext{
${ }^{25}$ For exposition of this fact, as well as the composition result mentioned earlier in the paragraph, see Alesina and Perotti (1997) and Alesina, Perotti and Tavares (1998).
} 
Table V

Left and Right and Success in Fiscal Adjustments

\begin{tabular}{l|rrrr}
\hline & Nr. Obs. & Loose & Tight & Success \\
\hline Left & & & & \\
Right & 233 & 0.21 & 0.14 & 0.40 \\
& 363 & 0.18 & 0.11 & 0.32 \\
\hline
\end{tabular}

We are then left with three facts about fiscal adjustments:

Fact 1 - Successful adjustments are those relying on spending cuts.

Fact 2 - The left is at least as successful as the right.

Fact 3 - The left adjusts by increasing taxes; the right by decreasing spending.

The way to reconcile these three facts is for left and right cabinets to have different success rates when pursuing adjustments in different ways. More specifically, it must be the case that, though the left is less likely to cut spending, when it does cut spending it is more successful than the right. Conversely, the right is more successful in the few instances when it increases taxes. This leads us to the hypotheses to be tested in this paper:

Hypothesis 1 - An adjustment pursued by cutting public expenditure is more likely to be successful if pursued by the left than by the right;

Hypothesis 2 - An adjustment pursued by increasing the level of taxes is more likely to be successful if pursued by the right than if it is pursued by the left.

We will test Hypotheses 1 and 2, in the following section, by estimating the effect of different adjustment characteristics on the persistence of adjustments. ${ }^{26}$

\footnotetext{
${ }^{26}$ We could also attempt to test the related hypotheses
} 


\section{Empirical Analysis}

\subsection{The Data}

We make use of two types of variables. The fiscal policy and other macroeconomic variables are taken from the OECD Economic Outlook, OECD (1997). The information on cabinet characteristics whether a coalition, a majority and the ideological location - is taken from Budge et al. (1993) and updated to 1995 by the author. The data set covers nineteen countries of the OECD between the years 1960 and $1995 .{ }^{27}$ Some definitions are clear cut: if more than one party held posts in the cabinet, it was classified as a coalition; if the parties supporting the cabinet held a majority of seats in the lower house of Parliament, it is classified as a majority. As to the ideological position, Budge et al. (1993) classify a cabinet as left (right) depending on whether at least a majority of the cabinet posts are controlled by parties classified as left/right. Party classifications derive from a cross-national survey of local experts, for the most part political scientists, reported in Castles and Mair (1984). Each party was placed on a segment representing left-right political orientation that is meant to be comparable across countries.

In our sample of adjustments, we include only adjustments initiated by left and right cabinets. The reasons to exclude fiscal adjustments undertaken by centrist cabinets are various. First, centrist cabinets are a very heterogeneous lot: they range from strong "caretaker" cabinets, with a clear mandate to address a particular problem (that could be economic, such as balancing the budget) to very weak coalition cabinets with no clear leadership or agenda. The interpretation of any results for centrist cabinets, in the context of ideology and credibility, would be rather unsatisfactory. Second, the results would likely be uninteresting: adjustments initiated by centrist cabinets are not successful at all in our sample, which would increase the noise in our search to ascertain the determinants of success. Nevertheless, we believe fiscal adjustments by centrist cabinets deserve a separate study. We also believe that the appropriate issues to be addressed in such a study would be the nature of coalition cabinets and the compromises they engender, not ideology, the particular source of credibility we are interested in.

Hypothesis 3 - An adjustment pursued by the left is more credible when it cuts spending;

Hypothesis 4 - An adjustment pursued by the right is more credible when it increases revenues.

\footnotetext{
${ }^{27}$ The countries are Australia, Austria, Belgium, Canada, Denmark, Finland, France, Germany, Greece, Ireland, Italy, Japan, Netherlands, Norway, Portugal, Spain, Sweden, the United Kingdom and the United States. Greece, Portugal and Spain are included only from appropriate dates in the mid-1970's, when these countries became democratic.
} 


\subsection{Specification}

Our basic specification attempts to capture the effect of the major sources of credibility on the probability of a successful fiscal adjustment. We compute Probit estimates of the success indicator on the independent variables, as suggested by the discussion in Section 2 above. Our sample includes adjustment years only, where adjustment is defined as a change in the deficit of at least -1.5 percent of GDP. The dependent variable takes the value 1 if the criterion for success is satisfied, that is, there is a decrease in the average deficit or the level of public debt of, respectively, 3 and 5 percent of GDP three years after the adjustment year. In years where none of these criteria are met, the dependent variable takes the value 0 .

The right-hand side variables we are most interested is the product of the ideological dummies (left and right) with the change in the fiscal variable in the adjustment year. We present results for the interaction of cabinet ideology with total spending, total revenues and each of their components. Ultimately we are interested in computing what is the effect on the probability of success of a 1 percent cut in spending/increase in taxes for left-wing cabinets and whether it is significantly different from the estimate for the right. In all Probit specifications we have included constants for left and right-wing cabinets to control for direct ideology effects on the likelihood of success, independently of the fiscal action undertaken. In this way, we can precisely estimate whether left and right have different success rates because they follow a specific policy. We will interpret any difference in effect as stemming from a difference in credibility. By examining each of the components of total spending and total revenues we are able to determine the categories that explain success and are thus important sources of credibility.

As to other independent variables, we have included in the basic specification controls for the following adjustment characteristics: ${ }^{28}$

- Type of cabinet initiating the adjustment - whether it is a coalition cabinet $(\mathrm{COAL}=1)$, with ministers drawn from two or more parties and whether it is a majority (MAJ=1);

- Stage of the business cycle - the rate of growth of real GDP ( $\triangle \mathrm{GDP})$ and the rate of growth of unemployment $(\triangle \mathrm{UNR})$ 
- Fiscal position at the time of the adjustment -- the level of public debt at the beginning of the adjustment year (LAGDEBT) and the change in public debt in the three years before the adjustment year (CHDEBT).

The dependent variable is computed based on information available only three years into the future relative to the independent variables, measured at the time of the initial deficit cut. For this reason, we do not think we run into serious problems of reverse causation. Moreover the independent variable of interest, the interaction of cabinet ideology and fiscal change, is not likely to be affected by the persistence of the adjustment. We can interpret the results as capturing a relationship running from fiscal changes to success and not the other way round.

\subsection{Results}

Table VI presents the Probit estimates. The dependent variable is a dummy taking the value 1 for success and each column includes as independent variable the interaction of the ideology dummies with the change in the fiscal variable whose name is at the top of the column. For example, in the first column in Table VI, row marked Left, we display the coefficient on the interaction of the dummy Left with the change in total expenditures, CHEXP. The coefficients on Left and Right reported thus represent how the likelihood of success changes with a 1 percent increase in a specific category of public spending by each type of cabinet. ${ }^{29} \mathrm{~A}$ negative sign indicates that a cut in the spending category is associated with higher likelihood of success.

For the change in total spending, CHEXP, it can be seen that the more a left-wing cabinet cuts spending the higher the likelihood of success. The coefficient on Left is significant at the 10 percent significance level whereas the coefficient on Right is not significant. The size of the coefficient is substantial: it suggests that a decrease in total spending of 1 percent of GDP leads to a 33 percent increase in the probability of success. When we look at the different components of spending we can verify that, whereas both left and right increase the chances of success when they cut government consumption (wage and non-wage), the significance is always higher for cuts by the left. Note how the left is particularly

\footnotetext{
${ }^{28}$ As to the size of the adjustment, there is a high correlation between changes in the deficit and changes in spending and its components so that we decided not to include it in the specification. However, results do not change when we add the deficit cut to the specification.

${ }^{29}$ All probits include, in addition, constants for left and right which we do not report.
} 
credible when it cuts government consumption, CHCG, or, more specifically, the government wage bill, CHCGW. The coefficients for these categories are significant at the 5 percent significance level. For other categories, such as subsidies and transfers, the evidence that the left is more credible is weak. As to public investment, cuts by the left do not increase the likelihood of success, whereas cuts by the right actually lower the probability of success. ${ }^{30}$ Overall our results are consistent with the now current view that expenditure cuts are an integral part of successful adjustments: for both left and right wing cabinets cuts in spending tend to be associated with persistent fiscal adjustments. However, with the exception of public investment, there is no evidence that the difference between left and right is significant. ${ }^{31}$ Nevertheless, for all components of spending, the size of the coefficient on the interaction of Left with the change in spending is larger than for the right, suggesting that the left derives more credibility from deficit cuts.

In regard to the control variables, the fiscal status has a strong and statistically significant effect on the likelihood of success in the expected way: the larger the level of public debt and the faster its recent growth the more persistent the adjustment. The coefficient on CHDEBT, the change in the level of public debt in the three years before adjusting, implies that a 1 percent recent increase in debt leads to a 2 percent increase in the probability of success. The value of 15 and 5 percent of GDP for average CHDEBT before successful and unsuccessful adjustments (see Table I) suggest that CHDEBT has a substantial effect on the probability of success. The coefficient on LAGDEBT is also important: an adjustment pursued at a debt level of 100 percent of GDP is 18 percent more likely to be persistent than the same adjustment at a 50 percent debt level. ${ }^{32}$ Finally, the government type has also a noticeable effect: coalition cabinets are less successful than other cabinets and minority cabinets tend to be more successful. Other things equal, an adjustment by a coalition cabinet is around 50 percent less likely to be persistent and an adjustment by a minority cabinet is 40 percent more likely to meet success. As to the stage of the business cycle at the time of adjustment, there is no evidence that it affects the persistence of adjustment in a noticeable way.

\footnotetext{
${ }^{30}$ This is consistent with previous work by Alesina and Perotti (1997) who show that unsuccessful adjustments tend to rely on cuts in public investment. Here we uncover that it is the right that is particularly unsuccessful when it relies on cuts in public investment.

${ }^{31}$ Given the difficulty of changing the entitlements associated with different categories of public spending, cuts by left or right wing cabinets may be seen as fairly persistent. This effect may overcome possible differences in credibility.

32 These results are consistent with Giavazzi and Pagano (1996) and Perotti (1997), but this is the first time the effect of these variables is quantified directly in terms of their impact on the likelihood of success.
} 


\section{Table IV}

\section{Determinants of Successful Adjustments}

Left, Right and Public Spending

\begin{tabular}{|c|c|c|c|c|c|c|c|}
\hline & CHEXP & CHCG & CHIG & CHCHTRF & CHSUB & CHCGW & CHCGNW \\
\hline LEFT*Fiscal Change & $\begin{array}{l}-0.33 \\
(-1.81)\end{array}$ & $\begin{array}{l}-0.55 \\
(-2.13)\end{array}$ & $\begin{array}{l}-0.08 \\
(-0.30)\end{array}$ & $\begin{array}{l}-0.47 \\
(-1.10)\end{array}$ & $\begin{array}{l}-0.58 \\
(-1.28)\end{array}$ & $\begin{array}{l}-0.68 \\
(-2.12)\end{array}$ & $\begin{array}{l}-1.34 \\
(-1.89)\end{array}$ \\
\hline RIGHT*Fiscal Change & $\begin{array}{l}-0.07 \\
(-0.01)\end{array}$ & $\begin{array}{l}-0.31 \\
(-1.24)\end{array}$ & $\begin{array}{l}0.56 \\
(1.45)\end{array}$ & $\begin{array}{l}-0.10 \\
(-0.34)\end{array}$ & $\begin{array}{l}-0.23 \\
(-0.40)\end{array}$ & $\begin{array}{l}-0.70 \\
(-1.57)\end{array}$ & $\begin{array}{l}-0.37 \\
(-0.88)\end{array}$ \\
\hline COAL & $\begin{array}{l}-0.46 \\
(-2.15)\end{array}$ & $\begin{array}{l}-0.58 \\
(-2.20)\end{array}$ & $\begin{array}{l}-0.50 \\
(-2.20)\end{array}$ & $\begin{array}{l}-0.51 \\
(-2.17)\end{array}$ & $\begin{array}{l}-0.51 \\
(-2.38)\end{array}$ & $\begin{array}{l}-0.66 \\
(-2.29)\end{array}$ & $\begin{array}{l}-0.56 \\
(-2.34)\end{array}$ \\
\hline MIN & $\begin{array}{l}0.43 \\
(2.07)\end{array}$ & $\begin{array}{l}0.38 \\
(1.76)\end{array}$ & $\begin{array}{l}0.36 \\
(1.79)\end{array}$ & $\begin{array}{l}0.43 \\
(1.74)\end{array}$ & $\begin{array}{l}0.49 \\
(2.14)\end{array}$ & $\begin{array}{l}0.34 \\
(1.68)\end{array}$ & $\begin{array}{l}0.37 \\
(1.75)\end{array}$ \\
\hline$\Delta \mathbf{U N R}$ & $\begin{array}{l}0.0024 \\
(0.24)\end{array}$ & $\begin{array}{l}0.0049 \\
(0.57)\end{array}$ & $\begin{array}{l}0.0061 \\
(0.67)\end{array}$ & $\begin{array}{l}0.0047 \\
(0.42)\end{array}$ & $\begin{array}{l}-0.0037 \\
(-0.41)\end{array}$ & $\begin{array}{l}0.0090 \\
(1.01)\end{array}$ & $\begin{array}{l}-0.0022 \\
(-0.27)\end{array}$ \\
\hline DEBT & $\begin{array}{l}0.0036 \\
(0.77)\end{array}$ & $\begin{array}{l}0.0043 \\
(0.85)\end{array}$ & $\begin{array}{l}0.010 \\
(1.84)\end{array}$ & $\begin{array}{l}0.0084 \\
(1.47)\end{array}$ & $\begin{array}{l}0.0085 \\
(1.60)\end{array}$ & $\begin{array}{l}0.0055 \\
(1.13)\end{array}$ & $\begin{array}{l}0.0066 \\
(1.27)\end{array}$ \\
\hline CHDEBT & $\begin{array}{l}0.021 \\
(2.14)\end{array}$ & $\begin{array}{l}0.021 \\
(2.11)\end{array}$ & $\begin{array}{l}0.020 \\
(1.93)\end{array}$ & $\begin{array}{l}0.016 \\
(1.42)\end{array}$ & $\begin{array}{l}0.019 \\
(1.92)\end{array}$ & $\begin{array}{l}0.014 \\
(1.63)\end{array}$ & $\begin{array}{l}0.029 \\
(2.53)\end{array}$ \\
\hline $\begin{array}{l}\text { Pseudo R2 } \\
\text { Log L } \\
\text { Number Observations }\end{array}$ & $\begin{array}{l}0.55 \\
-15.46 \\
53\end{array}$ & $\begin{array}{l}0.59 \\
-14.05 \\
53\end{array}$ & $\begin{array}{l}0.50 \\
-17.31 \\
53\end{array}$ & $\begin{array}{l}0.48 \\
-17.82 \\
53\end{array}$ & $\begin{array}{l}0.49 \\
-17.66 \\
53\end{array}$ & $\begin{array}{l}0.61 \\
-13.54 \\
53\end{array}$ & $\begin{array}{l}0.54 \\
-15.96 \\
53\end{array}$ \\
\hline
\end{tabular}

Note: All Probit specifications include different constants for adjustments initiated by the right and by the left, not reported. The independent variables Left ${ }^{*}$ Fiscal Change and Right*Fiscal Change are the product of the ideological dummies Left and Right by the yearly change in the variable at the top of each column. For each independent variable we report $(\delta \mathrm{F} / \delta \mathrm{x})$, i.e., the marginal change in the probability of success for the average values of the independent variables. In parentheses we report the t-statistic. See Appendix I for a complete description of the variables. 
Table VII

Determinants of Successful Adjustments

Left, Right and Government Revenues

\begin{tabular}{|c|c|c|c|c|c|c|}
\hline & CHREV & CHTY & CHTIND & CHOTAX & CHTYB & CHTYH \\
\hline LEFT*Fiscal Change & $\begin{array}{l}-0.21 \\
(-1.50)\end{array}$ & $\begin{array}{l}-0.21 \\
(-1.57)\end{array}$ & $\begin{array}{l}0.21 \\
(0.52)\end{array}$ & $\begin{array}{l}-0.46 \\
(-1.03)\end{array}$ & $\begin{array}{l}-0.26 \\
(-1.49)\end{array}$ & $\begin{array}{l}-0.06 \\
(-0.31)\end{array}$ \\
\hline${\text { RIGHT*}{ }^{\star} \text { Fiscal Change }}$ & $\begin{array}{l}0.17 \\
(1.13)\end{array}$ & $\begin{array}{l}0.26 \\
(1.45)\end{array}$ & $\begin{array}{l}-0.06 \\
(-0.26)\end{array}$ & $\begin{array}{l}0.48 \\
(1.18)\end{array}$ & $\begin{array}{l}0.10 \\
(0.54)\end{array}$ & $\begin{array}{l}0.17 \\
(0.76)\end{array}$ \\
\hline COAL & $\begin{array}{l}-0.55 \\
(-2.24)\end{array}$ & $\begin{array}{l}-0.57 \\
(-2.32)\end{array}$ & $\begin{array}{l}-0.50 \\
(-2.11)\end{array}$ & $\begin{array}{l}-0.51 \\
(-2.11)\end{array}$ & $\begin{array}{l}-0.51 \\
(-2.18)\end{array}$ & $\begin{array}{l}-0.56 \\
(-2.25)\end{array}$ \\
\hline MIN & $\begin{array}{l}0.49 \\
(2.28)\end{array}$ & $\begin{array}{l}0.48 \\
(2.23)\end{array}$ & $\begin{array}{l}0.38 \\
(1.85)\end{array}$ & $\begin{array}{l}0.54 \\
(2.17)\end{array}$ & $\begin{array}{l}0.42 \\
(2.06)\end{array}$ & $\begin{array}{l}0.37 \\
(1.75)\end{array}$ \\
\hline$\Delta \mathbf{U N R}$ & $\begin{array}{l}0.00025 \\
(0.02)\end{array}$ & $\begin{array}{l}-0.0023 \\
(-0.22)\end{array}$ & $\begin{array}{l}0.0002 \\
(0.02)\end{array}$ & $\begin{array}{l}0.0057 \\
(0.52)\end{array}$ & $\begin{array}{l}-0.0028 \\
(-0.03)\end{array}$ & $\begin{array}{l}0.001 \\
(0.11)\end{array}$ \\
\hline DEBT & $\begin{array}{l}0.0098 \\
(1.77)\end{array}$ & $\begin{array}{l}0.012 \\
(2.07)\end{array}$ & $\begin{array}{l}0.0087 \\
(1.61)\end{array}$ & $\begin{array}{l}0.0067 \\
(1.24)\end{array}$ & $\begin{array}{l}0.0080 \\
(1.61)\end{array}$ & $\begin{array}{l}0.0092 \\
(1.72)\end{array}$ \\
\hline CHDEBT & $\begin{array}{l}0.019 \\
(1.96)\end{array}$ & $\begin{array}{l}0.018 \\
(1.85)\end{array}$ & $\begin{array}{l}0.020 \\
(1.93)\end{array}$ & $\begin{array}{l}0.017 \\
(1.65)\end{array}$ & $\begin{array}{l}0.021 \\
(2.10)\end{array}$ & $\begin{array}{l}0.021 \\
(2.10)\end{array}$ \\
\hline $\begin{array}{l}\text { Pseudo R2 } \\
\text { Log L } \\
\text { Number Observations }\end{array}$ & $\begin{array}{l}0.52 \\
-16.52 \\
53\end{array}$ & $\begin{array}{l}0.52 \\
-16.73 \\
53\end{array}$ & $\begin{array}{l}0.46 \\
-18.61 \\
53\end{array}$ & $\begin{array}{l}0.50 \\
-17.10 \\
53\end{array}$ & $\begin{array}{l}0.50 \\
-17.40 \\
53\end{array}$ & $\begin{array}{l}0.46 \\
-18.52 \\
53\end{array}$ \\
\hline
\end{tabular}

Note: All Probit specifications include different constants for adjustments initiated by the right and by the left, not reported. The independent variables Left*Fiscal Change and Right*Fiscal Change are the product of the ideological dummies Left and Right by the yearly change in the variable at the top of each column. For each independent variable we report $(\delta \mathrm{F} / \delta \mathrm{x})$, i.e., the marginal change in the probability of success for the average values of the independent variables. In parentheses we report the t-statistic. See Appendix I for a complete description of the variables. 
Table VII presents results for changes in revenues and its components. The results are clearer than for public spending: the likelihood of the cut in the deficit being persistent increases with tax rises by right-wing cabinets but decreases when it is the left that increases taxes. These results are in accordance with Hypothesis 2, presented in section 3, that the left is less credible than the right when it increases taxes. The difference between the likelihood of success for the left and the right is significant for total revenues and for all sub-categories, with the exception of indirect taxes and direct business taxes. The magnitude of this difference varies but is substantial: the same 1 percent increase in taxes is 0.38 less likely to lead to a persistent adjustment if pursued by the left.

Summarizing the results in this section, we find support for our hypothesis that left and right cabinets signal commitment to fiscal adjustment by changing fiscal variables in a way that is contrary to their partisan interests. Both types of cabinets, left and right, gain credibility by cutting spending but there is some evidence that the effect is stronger for the left. On the taxation side, our results support the hypothesis that the left is less credible than the right when it cuts deficits by increasing taxes. The differences in likelihood of success are important.

The issue that naturally arises in view of the results in Tables VI and VII is whether it is credibility that is at the origin of the different reactions to fiscal policy changes by the Left and the Right. In this section, we suggest a possible path to address the issue. If credibility is at the root of the response to the fiscal action, it should be captured by variables that are affected by expectations about the future. Private investment is precisely this type of variable: if an adjustment is credible and believed to be persistent it is expected to lead to lower interest rates in the future. Investment should respond positively to the deficit cut.

In Table VIII we present the average growth in the shares of Housing Investment, Business Fixed Investment and Private Consumption in GDP for different adjustments. We divide the adjustments by the Left and by the Right into those that were mostly undertaken by cuts in spending (CHEXP<-0.02) or increases in taxes (CHREV >0.02). Table VII displays the rate of growth of these three variables for the year of adjustment, for one year after the adjustment and for two years after the adjustment. We find that when the Left adjusts by cutting spending both housing investment and business fixed investment grow at 
higher rates relative to when the Left adjusts by raising taxes. In the case of fiscal adjustments initiated by right-wing cabinets and business fixed investment the opposite is true: it is after adjustments undertaken by increasing taxes that business fixed investment grows the most. In the case of adjustments by the right and housing investment the results are mixed. As for private consumption, there is less evidence of a difference in growth rates depending on the pair ideology - fiscal action.

Table VIII

Left and Right, Composition of Adjustments and Private Demand

\begin{tabular}{l|cccc}
\hline & \multicolumn{1}{|l}{ Left } & \multicolumn{3}{l}{ Right } \\
\hline & CHEXP<-0.02 & CHREV $>0.02$ & CHEXP<-0.02 & CHREV 0.02 \\
\hline & & & & \\
INVPRIV & 1.4 & -1.8 & 3.3 & 6.3 \\
INVPRIV + 1 & 7.9 & 0.4 & 6.6 & 2.2 \\
INVPRIV + 2 & 7.1 & -2.5 & 4.6 & 7.2 \\
& & & & \\
INVHOU & 0.8 & -5.1 & -2.3 & -2.9 \\
INVHOU + 1 & 1.5 & -2.6 & -0.8 & -5.4 \\
INVHOU + 2 & 3.8 & -0.5 & -2.2 & 1.4 \\
& & & & \\
INVBUS & 1.8 & 0.6 & 6.6 & 10.3 \\
INVBUS + 1 & 10.0 & 1.0 & 9.9 & 6.3 \\
INVBUS + 2 & 9.1 & -4.6 & 7.7 & 9.9 \\
& & & & \\
CONS & -1.3 & 0.9 & -0.2 & 0.3 \\
CONS + 1 & -0.5 & 1.0 & -0.4 & -0.5 \\
CONS + 2 & 0.2 & 0.7 & -0.9 & 0.04 \\
\end{tabular}

Note: Values are in percent of GDP. The table considers only the sub-sample of fiscal adjustments, i.e., years when CHDEF $<-0.015$. The sample of adjustments is subdivided into adjustments relying on spending and relying on revenues, that is. Where CHEXP $<-0.02$ and CHREV $>0.02$, respectively. The column variables are the rate of growth of the shares of housing investment, business investment and private consumption in GDP in the year of adjustment, one and two years after adjustment.

Table IX below presents results for Ordinary Least Square regressions of adjustment characteristics on the growth rate investment, its components and private consumption. The regressors included in the specification are the same as for Tables VI and VII above but are not their coefficients are not reported for reasons of parsimony. The first noticeable fact is that for private investment and its components, housing and business fixed investment, we find evidence that, in adjustment years, the higher the cut in spending by a left-wing cabinet the higher the growth rate in investment. Cuts in spending by the right have the same sign (that is, they foster investment) but their magnitude is smaller. For housing investment cuts by the right actually have a depressing effect. These results are consistent with the view that spending cuts by the left are more credible. As for increases in taxes, we can verify that increases by the left have a depressing effect on investment and both its components whereas increases in taxes by the 
right have a stimulative effect on investment. Again these results are compatible with the hypothesis that right-wing cabinets that adjust by raising taxes are more credible. Finally, confirming the summary statistics in Table VIII, private consumption seems to respond in a similar way to fiscal policy changes, whether pursued by the left or the right.

Table IX

Left, Right, Composition of Adjustments and Determinants of Private Demand

\begin{tabular}{|c|c|c|c|c|}
\hline & Left ${ }^{\star} C H E X P$ & Right $^{*} C H E X P$ & Left ${ }^{\star} C H R E V$ & Right $^{\star} \mathrm{CHREV}$ \\
\hline INVPRIV & $\begin{array}{l}-1.17 \\
(-1.45)\end{array}$ & $\begin{array}{c}-0.66 \\
(-0.78)\end{array}$ & $\begin{array}{l}-1.44 \\
(-1.92)\end{array}$ & $\begin{array}{c}1.00 \\
(0.68)\end{array}$ \\
\hline INVPRIV + 1 & $\begin{array}{c}-2.65 \\
(-2.68)\end{array}$ & $\begin{array}{l}-1.23 \\
(-1.16)\end{array}$ & $\begin{array}{c}1.63 \\
(-1.35)\end{array}$ & $\begin{array}{c}0.88 \\
(0.49)\end{array}$ \\
\hline INVPRIV + 2 & $\begin{array}{c}-3.80 \\
(-2.62)\end{array}$ & $\begin{array}{c}-0.34 \\
(-0.20)\end{array}$ & $\begin{array}{c}-2.32 \\
(-1.44)\end{array}$ & $\begin{array}{c}4.10 \\
(1.92)\end{array}$ \\
\hline INVHOU & $\begin{array}{c}-2.42 \\
(-2.65)\end{array}$ & $\begin{array}{c}1.13 \\
(0.50)\end{array}$ & $\begin{array}{c}-2.84 \\
(-2.89)\end{array}$ & $\begin{array}{c}0.92 \\
(0.46)\end{array}$ \\
\hline INVHOU + 1 & $\begin{array}{c}-2.92 \\
(-2.26)\end{array}$ & $\begin{array}{c}-0.65 \\
(-0.54)\end{array}$ & $\begin{array}{c}-2.45 \\
(-1.82)\end{array}$ & $\begin{array}{c}1.21 \\
(0.78)\end{array}$ \\
\hline INVHOU + 2 & $\begin{array}{l}-1.69 \\
(-1.17)\end{array}$ & $\begin{array}{c}1.26 \\
(0.98)\end{array}$ & $\begin{array}{c}-0.68 \\
(-0.60)\end{array}$ & $\begin{array}{c}3.98 \\
(2.13)\end{array}$ \\
\hline INVBUS & $\begin{array}{c}-0.28 \\
(-0.26)\end{array}$ & $\begin{array}{l}-1.56 \\
(-1.69)\end{array}$ & $\begin{array}{c}-0.37 \\
(-0.36)\end{array}$ & $\begin{array}{c}0.82 \\
(0.50)\end{array}$ \\
\hline INVBUS + 1 & $\begin{array}{c}-2.50 \\
(-1.74)\end{array}$ & $\begin{array}{l}-1.42 \\
(-1.14)\end{array}$ & $\begin{array}{c}-1.42 \\
(-0.93)\end{array}$ & $\begin{array}{c}0.77 \\
(0.38)\end{array}$ \\
\hline INVBUS + 2 & $\begin{array}{c}-5.41 \\
(-3.25)\end{array}$ & $\begin{array}{c}-1.28 \\
(-0.64)\end{array}$ & $\begin{array}{l}-3.58 \\
(-1.80)\end{array}$ & $\begin{array}{c}3.93 \\
(1.68)\end{array}$ \\
\hline CONS & $\begin{array}{c}0.81 \\
(4.20)\end{array}$ & $\begin{array}{c}0.20 \\
(1.33)\end{array}$ & $\begin{array}{c}0.86 \\
(4.01)\end{array}$ & $\begin{array}{c}0.44 \\
(1.63)\end{array}$ \\
\hline CONS + 1 & $\begin{array}{c}0.38 \\
(1.79)\end{array}$ & $\begin{array}{c}0.19 \\
(0.66)\end{array}$ & $\begin{array}{c}0.53 \\
(2.22)\end{array}$ & $\begin{array}{c}0.41 \\
(1.06)\end{array}$ \\
\hline CONS + 2 & $\begin{array}{l}0.06 \\
(0.47)\end{array}$ & $\begin{array}{l}0.16 \\
(0.23)\end{array}$ & $\begin{array}{l}0.10 \\
(0.87)\end{array}$ & $\begin{array}{l}0.15 \\
(0.44)\end{array}$ \\
\hline
\end{tabular}

Note: Robust standard errors in parentheses. All specifications include all the independent variables displayed in Tables VI and VII but the coefficients and standard values are not reported for reasons of parsimony. The column variables are the rate of growth of the shares of housing investment, business investment and private consumption in GDP in the year of adjustment, one and two years after adjustment.

\section{Conclusion}

This paper draws on the assumption that the cabinets of the left favor a larger size of government than right-wing cabinets to ask the question: does the pair cabinet ideology - fiscal action affect the 
likelihood of success in cutting the deficit? The reasoning is simple, if left-wing cabinets favor a larger government size than right-wing cabinets, a cut in spending by the left or an increase in taxes by the right signal commitment to decrease the deficit. By pursuing the course of action that is not favored by their constituents, cabinets signal the need for adjustment and gain credibility.

We document, from survey data, empirical observation and the literature on partisanship and fiscal policy, that the left has a preference for higher public spending. The difference in average yearly change in spending and revenues between left and right is consistent with the prior but it is during fiscal adjustments that it is starker: the left relies mostly on tax increases taxes and the right on spending cuts when pursuing fiscal adjustments. We estimate how fiscal changes by each cabinet type affect the likelihood of success and find evidence that:

1. both left and right are credible when they cut spending, even though the effect is stronger for the left; moreover, it is by cutting government wages that cabinets are the most credible; right wing cabinets that cut public investment, lose rather than gain credibility.

2. when the adjustment is pursued by tax increases the left loses credibility while the right gains credibility; direct taxes and other taxes are the categories where this effect is most evident.

We investigate whether similar fiscal policy actions by left and right-wing cabinets have different impact on private investment and consumption. We find little evidence of the latter but private investment and both its components, housing and business investment, seem to react differently to deficit cuts by the left or the right. Even if spending cuts tend to increase investment whatever the cabinet, expenditure cuts by the left lead to a stronger positive response of investment than expenditure cuts by the right. The response to taxes is even more symmetrical, while increases in taxes by the right lead to increases in investment, increases in taxes by the left actually depress investment. These results are consistent with the idea that cabinets derive credibility by pursuing fiscal policy actions known not to be their preferred ones.

In sum, our results are consistent with previous results on composition of adjustment and success that show that adjustments that rely on spending cuts are more likely to be persistent. We also confirm that coalition cabinets and majority cabinets are more likely to be successful in cutting the deficit and that when debt is high or has been growing fast in the recent past the likelihood of success in adjustment increases. But we go beyond earlier results and present evidence that the left is more credible than the 
right when cutting spending. When increasing taxes the right gains credibility whereas the left loses credibility so that the difference between the two types of cabinets is significant and accords with our priors. These effects are present for several spending and revenue categories and the size of the impact on the probability of success is important. The message of this paper is simply stated: it is not only what you do, it's how you do it and who you are. 


\section{References}

Alesina, A., and A. Drazen, 1991, "Why are Stabilizations Delayed?", American Economic Review, December, $81: 1170-88$.

Alesina, A., and R. Perotti, 1997, "Fiscal Adjustments in OECD Countries: Composition and Macroeconomic Effects", IMF Staff Papers. June, 44 : 210-48.

Alesina A., R. Perotti and J. Tavares, 1998, "The Political Economy of Fiscal Adjustments", The Brookings Papers on Economic Activity, Spring 1998.

Alt, J. and R. Lowry, 1994, "Divided Government, Fiscal Institutions and Budget Deficits: Evidence from the States", American Political Science Review, December, 88: 811-828.

Barro, R., 1989, "The Neoclassical Approach to Fiscal Policy", in R. Barro (ed.), Modern Business Cycle Theory, Harvard University Press, Cambridge, Massachusetts, pp. 178-235.

Bertola, G. and A. Drazen, 1993, "Trigger Points and Budget Cuts: Explaining the Effects of Fiscal Austerity", American Economic Review, March, 83 : 11-26.

Blais, A., D. Blake and S. Dion, 1993, "Do Parties Make a Difference? Parties and the Size of Government in Liberal Democracies ", American Journal of Political Science, February, 37: 40-62.

Blanchard, O., 1990, "Comments on Giavazzi and Pagano", in O. Blanchard and S. Fischer, (eds.), NBER Macroeconomics Annual 1990, Cambridge, MA, MIT Press, pp. 112-117.

Blinder, A. and D. Holtz-Eakin, 1984, "Public Opinion and the Balanced Budget", American Economic Review Papers and Proceedings, May, 74: 144-49.

Budge, I., H. Kemam and J. Woldendrop, 1993, "Political Data 1945-90", European Journal of Political Research, Special Issue, 24: 1-120.

Cameron, D., 1978, "The Expansion of the Public Economy: A Comparative Analysis", December, 72: 1243-1261.

Cameron, D., 1985, "Does Government Cause Inflation? Taxes, Spending and Deficits", in L. Lindberg and C. Maier (eds.), The Politics of Inflation and Economic Stagnation: Theoretical Perspectives and International Case Studies, Brookings Institution, Washington, DC, pp. 224-279.

Castles, F., 1982, "The Impact of Parties in Public Expenditure", in F. Castles, (ed.), The Impact of Parties: Politics and Policies in Democratic Capitalist States, SAGE Publications, Beverly Hills, California.

Castles, F. and P. Mair, 1984, "Left-Right Political Scales: Some "Expert"' Judgements ", European Journal of Political Research, 12: 73-88. 
Cowart, A., 1978, "The Economic Policies of European Governments, Part II: Fiscal Policy", British Journal of Political Science, 8: 425-39.

Cukierman, A., and M. Tommasi, 1998, "When Does It Take a Nixon To Go To China", American Economic Review, March, 88: 180-197.

Fuller, D., Alston, R., and M. Vaughan, 1995, "The Split Between Political Parties on Economic Issues: A Survey of Republicans, Democrats, and Economists", Eastern Economic Journal, 21: 227-38.

Gallup Organization, 1990, The Gallup Poll Monthly, May.

Giavazzi, F., and M. Pagano, 1990, "Can Severe Fiscal Adjustment be Expansionary? Tales of Two Small European Countries" in O. Blanchard, and S. Fischer, (eds.), NBER Macroeconomics Annual 1990, pp. 75-111, MIT Press, Cambridge, Massachusetts.

Giavazzi, F., and M. Pagano, 1996, "Non-Keynesian Effects of Fiscal Policy Changes: International Evidence and the Swedish Experience", Swedish Economic Policy Review, Spring, 3 : 67-103.

Golden, D. and J. Poterba, 1980, "The Price of Popularity: The Political Business Cycle Reexamined", American Journal of Political Science, 24: 696-714.

Grilli, V., D. Masciandaro and G. Tabellini, 1991, "Political and Monetary Institutions and Public Financial Policies in the Industrial Countries", Economic Policy, October, 6 : 341-92.

Hahm, S., M. Kamlet and D. Mowery, 1995, "Influences on Deficit Spending in Industrialized Countries", Journal of Public Policy, 15: 183-97.

Hicks, F. and D. Swank, 1992, "Politics, Institutions, and Welfare Spending in Industrialized Democracies 1960-82", American Political Science Review, September, 86: 658-674.

Kay, A., H. Henderson, F. Steeper, S. Greenberg and C. Blunt, 1995, "Who Will Reconnect With the People: Republicans, Democrats, or ... None of the Above?," Americans Talk Issues, August, Survey \#28.

Lewis-Beck, M., 1988, "Economics and Elections: The Major Western Democracies", Ann Arbor, University of Michigan Press.

Lewis-Beck, M., and T. Rice, 1985, "Government Growth in the United States", Journal of Politics, 47: 227.

Organization of Economic Cooperation and Development, 1997, Economic Outlook, OECD, Paris

Pencavel, J., 1986, "Labor Supply of Men: A Survey", in O. Ashenfelter and R. Layard, (eds.), Handbook of Labor Economics, Volume 1, North Holland, Amsterdam. 
Perotti, R., 1997, "Fiscal Policy When Things Are Going Badly", Unpublished paper, Columbia University.

Persson, T. and L. Svensson, 1989, "Why a Stubborn Conservative Would Run a Deficit: Policy with Time-Inconsistent Preferences", Quarterly Journal of Economics, May, 104 : 325-345.

Piketty, T., 1995, "Social Mobility and Redistributive Politics", Quarterly Journal of Economics, 110: 551-84.

Political Handbook of the World, 1996, McGraw-Hill, New York.

Rice, T., 1986, “The Determinants of Western European Government Growth, 1950-1980", Comparative Political Studies, 19: 233-59.

Roubini, N., and J. Sachs, 1989, "Political and Economic Determinants of Budget Deficits in the Industrial Democracies", European Economic Review, 33: 903-33.

Samuelson, R., 1996, "The Debate We Need ...", Newsweek, 7 October 1996.

Spolaore, E., 1993, "Policy Making Systems and Economic Efficiency, Coalition Governments vs. Majority Government", Unpublished paper, Harvard University.

Sutherland, A., 1997, "Fiscal Crisis and Aggregate Demand: Can High Public Debt Reverse the Effects of Fiscal Policy?", Journal of Public Economics, August, 65 : 147-62.

Swank, D., 1988, "The Political Economy of Government Domestic Expenditure in The Affluent Democracies, 1960-1980 ", American Journal of Political Science, 32: 1120-50. 


\section{Appendix I}

\section{The Data}

The sample period is 1960-1995 for the fiscal and the cabinet change data and 1975-1993 for the popularity data. The data set includes Australia, Austria, Belgium, Canada, Denmark, Finland, France, Germany, Greece, Ireland, Italy, Japan, Netherlands, Norway, Portugal, Spain, Sweden, UK and USA. Greece, Portugal and Spain are included only after they became democratic in the mid-1970's.

\section{I.1. - CABINET DATA}

The cabinet data for the 1960-1995 time period was taken from Budge, Kemam and Woldendorp (1993) and subsequent updates. The Political Handbook of the World was used to compute the changes for 1995. Data for Greece, Portugal and Spain was also assembled by the authors from the Political Handbook of the World in accordance with the criteria used by Budge et al. (1993).

The cabinet variables used in this paper are:

LEFT (Left wing cabinet) - dummy variable which takes the value 1 if the cabinet which is in power for most of the calendar year is classified as left in Budge, Kemam and Woldendrop (1993). The ideological index developed by Budge et al. (1993) locates the cabinet on a left-right scale according to its ideology:

- $\quad 1$ if the share of right-wing seats in government (or of supporting parties in parliament in cases where parties explicitly support a cabinet without taking any seats in it) is equal or larger to $2 / 3$;

- 2 if the share of right and center parties is between $1 / 3$ and $2 / 3$ each;

- 3 if the center parties is larger than 50 percent or if left and right parties form a government with no dominant party;

- 4 and 5 like 1 and 2 but with left-wing parties. For the US. a Democrat president is classified as a 1 and a Republican as a 5.

RIGHT is a dummy variable which takes the value 1 if the cabinet which holds power for the largest part of the calendar year is classified as right in the above data set.

COAL (Coalition cabinet) - dummy variable that takes the value 1 if a coalition cabinet is in power, that is, a cabinet which includes ministers from two or more parties. Coalitions can be of three types: minority, minimal winning and surplus coalitions.

MIN (Minority cabinet) - dummy variable that takes the value 1 if the cabinet has no majority support in parliament. Minorities can be single party or coalition cabinets.

\section{I.2. - NATIONAL ACCOUNTS DATA}

The fiscal data is from OECD (1997) and covers the 1960-1995 time period. The variables computed from the original OECD data set are: 
CHDEF (Change in Deficit) - yearly change in the primary deficit as a share of Gross Domestic Product. All other fiscal variables are defined in a similar way: CHEXP and CHREV are, respectively, the changes in primary public expenditures and in public revenues as a share of GDP; CHCG is government consumption, CHIG investment, CHTRF transfers and CHSUB subsidies; CHCGW and CHCGNW are the wage and non-wage components of government consumption; CHTY is direct taxes, CHTIND indirect and CHOTAX other taxes; CHTYH is direct taxes on households and CHTYB direct taxes on businesses.

DEBT (Public Debt) - Public debt as a share of Gross Domestic Product at the beginning of the fiscal year. CHDEBT (Change in Public Debt) - Change in the level of public debt as share of Gross Domestic Product in the last three years, up to the beginning of the current fiscal year.

$\Delta$ GDP (Rate of Growth of real GDP) - ratio of real GDP in the current year to real GDP the year before minus 1 .

$\Delta \mathbf{U N R}$ (Growth of the Unemployment Rate) - change in the unemployment rate between the current year and the year before divided by the unemployment rate the year before.

$\triangle$ PRIVINV (Private investment) - the growth rate of private investment as a share of GDP. $\triangle$ HOUINV is the growth rate of investment in housing as a share of GDP. $\triangle B U S I N V$ is the growth rate of business investment as a share of GDP. The sum of $\triangle$ HOUINV and $\triangle B U S I N V$ equals $\triangle$ PRIVINV. 


\section{Appendix II \\ Fiscal Adjustments in the OECD}

\section{Fiscal Adjustments in the OECD by Country}

\begin{tabular}{l|c}
\multicolumn{2}{c}{ (1960-1992) } \\
\hline & Number of Adjustments \\
\hline Australia & 4 \\
Austria & 3 \\
Belgium & 2 \\
Canada & 3 \\
Denmark & 5 \\
Finland & 7 \\
France & 2 \\
Germany & 4 \\
Greece & 5 \\
Ireland & 7 \\
Italy & 6 \\
Japan & 1 \\
Netherlands & 2 \\
Norway & 3 \\
Portugal & 5 \\
Spain & 2 \\
Sweden & 3 \\
UK & 3 \\
USA & 3 \\
Note: Ascal adjustment is a change in the primary deficit by at least - 1.5 percent of GDP in a single year. & \\
\end{tabular}


Fiscal Adjustments in the OECD by Year

\begin{tabular}{l|c}
\multicolumn{2}{c}{$(1960-1992)$} \\
\hline & Number of Adjustments \\
\hline 1961 & 1 \\
1963 & 1 \\
1964 & 1 \\
1965 & 1 \\
1966 & 1 \\
1967 & 2 \\
1969 & 4 \\
1972 & 1 \\
1973 & 2 \\
1974 & 1 \\
1976 & 7 \\
1977 & 5 \\
1979 & 1 \\
1980 & 2 \\
1981 & 1 \\
1982 & 3 \\
1983 & 3 \\
1984 & 9 \\
1985 & 3 \\
1986 & 5 \\
1987 & 6 \\
1988 & 1 \\
1989 & 1 \\
1990 & 5 \\
1991 & 1 \\
1992 & 1 \\
\hline
\end{tabular}

Note: A fiscal adjustment is a change in the primary deficit by at least -1.5 percent of GDP in a single year. 